\title{
ENCONTROS EM AD: ENTRE MEMÓRIAS E EFEITOS DE LEITURA
}

\begin{abstract}
ADORNO, G. et al. (Orgs.). Encontros na Análise de Discurso: efeitos de sentidos entre continentes. Campinas: Editora da Unicamp, 2019.
\end{abstract}

Iago Moura Melo

Universidade Estadual de Santa Cruz, UESC, Ilhéus, BA, Brasil

Raphael de Morais Trajano

Faculdade de Letras da Fundação Técnico-Educacional Souza Marques,

Rio de Janeiro, RJ, Brasil

$\mathrm{O}$ conjunto não-homogêneo de textos organizados sob o título Encontros na análise de discurso (doravante Encontros) resulta de um trabalho teórico de enorme densidade, entusiasmo e acuidade, em que se engaja o Coletivo de trabalho: discurso e transformação (Contradit). Trata-se do primeiro projeto subscrito pelo Contradit enquanto coletivo, antecedido por muitos outros trabalhos cuja circulação costumava ser menos abrangente, tais como a organização de simpósios temáticos em eventos, publicação de artigos em periódicos qualificados, encontros presenciais e não presenciais, estes últimos realizados nos domínios do digital, com vistas à realização de um trabalho que indistingue teoria e prática, no qual a teoria é tomada como lugar de agitação no histórico modo de constituição, formulação e circulaçáo dos discursos (em que se destacam, entre outros, os discursos científico e acadêmico).

O processo de produção editorial, entretanto, falha pelo apagamento de parte dos organizadores quando de sua impressão oficial - além da ausência da rubrica do coletivo já na capa do livro - sob, talvez, o atomismo injustificado de que apenas "indivíduos" poderiam ser "reconhecidos" como organizadores. Podemos, assim, pensar em como é próprio ao capitalismo disjungir causa motriz e causa final, inclusive, em se tratando de um tipo de trabalho a que insistimos, em coro a Althusser, denominar "teórico". Nessa linha, a dita falha sintomatiza o quanto ainda precisamos suspeitar de nossas práticas de escrita $^{1}$, sobretudo quando tais implicam num

\footnotetext{
${ }^{1}$ A utilização da primeira pessoa ao longo desta resenha estabelece relação de implicação epis-
} 
processo ritualizado altamente vigiado como é o da produção de um livro. O gregarismo da memória, essa que se conta aqui e acolá, insiste sob um compromisso ideológico que diz do real de nossa existência, de tudo isso que compreendemos como sendo a nossa formaçáo social. Disso nem mesmo uma modalizaçáo autonímica, materializada numa errata adesiva e pouco expressiva, pode nos desincumbir.

Dito isso, gostaríamos de introduzir um pouco do que comparece no momento mesmo dessa nossa recepçáo do Encontros. No estágio atual da formação social capitalista no Brasil, no interior de tantas contradiçóes em que o discurso vem provar mais ainda a sua materialidade e reivindicar, sobremodo, o político, náo podemos nos furtar em tomar uma posiçáo implicada em tudo isso e, dessa maneira, devemos reconhecer que o convite, de muitas formas pronunciado, à re-materialização da prática teóricoanalítica em AD (na entrevista com Marie-Anne Paveau, por exemplo, ele se dá sob a fórmula da re-politização) é demasiado assertivo e muito acrescenta à história dessa disciplina no Brasil e aos seus desdobramentos atuais, pelo que um posicionamento nosso em defesa de causas ditas como perdidas e de um princípio de entremeio é fatalmente oportuno e, mais do que isso, exige-se. Nesse sentido, as nove entrevistas somadas ao anexo de autoria de Michel Pêcheux mostram-se bastante frutíferos para o sopesamento de nossa prática em $\mathrm{AD}$ na América Latina.

Encontros potencializa a tônica da abertura desde os múltiplos efeitosleitura que se anunciam no possível socio-historicamente situado. Isso, pelas conjecturas que se empreendem, pelas retomadas mnemônicas, ou mesmo pelas pinceladas (auto)biográficas e biografemáticas, que bastante vêm conjugar pormenores de lembrança/esquecimento ao sentido (particípio do verbo sentir) de amabilidade em relação à autoria de Pêcheux e de tantos outros. É, portanto, bastante elogiável a seleção dos nove entrevistados: Eni Orlandi, Roselis Maria Batista, Julieta Haidar, Francine Mazière, Régine Robin, Jacques Guilhaumou, Paul Henry, Michel Plon e MarieAnne Paveau.

Outro aspecto a se destacar é quanto à assertividade das provocaçóes endereçadas aos entrevistados, as quais traduzem maturação e vital comprometimento por parte do Contradit quanto à prática da $\mathrm{AD}$. São convocadas outras territorialidades epistêmicas, além da brasileira, para contra-assinarem com e nesse trabalho discursivo de transformação. As

temológica e política por parte destes autores, enquanto leitores do texto resenhado, em relação ao campo de estudos a que se filiam, qual seja o da Análise Materialista de Discurso. 
perguntas performam ousadia e revolta, polemizam questôes nevrálgicas que acompanham nossa prática teórica, desde a problemática da designaçáo da disciplina aos dilemas a que podemos chamar sofoclianos.

A partir desse horizonte, o materialismo, tal como ele constantemente se reinventa, interpela-nos não a decifrar, mas a compreender aquilo que joga na constituição desse dispositivo teórico que assumimos para mediar a relação, sempre-já nossa, com a discursividade da língua encravada na história. Isso, sob pena de, pelo efeito da medusa, permitir que ele, o dispositivo de escuta, seja, em sua especificidade, devorado pelo recalque do ideológico.

Encontros diz-nos da "resistência" das ideologias teóricas, presentes no momento mesmo da constituição científica da AD na França. Historiciza a introdução e ampliação da aludida disciplina no âmbito de uma escuta tipicamente brasileira. Fala das exclusóes, apagamentos e defesas realizados por efeito de desdobramentos de leitura no México, em decorrência da ousadia de um empreendimento teórico anti-subjetivista, alicerçado muito intimamente na figura de um intelectual bem-humorado e que muito vagamente procurou lugar nas instituiçóes.

A leitura das conversas com Orlandi, Batista, Haidar e Henry nos engaja na defesa do caráter "a construir" do dispositivo de escuta que fazemos funcionar. Somos convocados a reafirmar a história da ciência como um processo dialético, como é próprio a um princípio de corte continuado, sem acolher uma teleologia de fases mais ou menos importantes ${ }^{2}$. É preciso atentar, cada vez mais, para "[...] o fato de que Pêcheux sempre trabalhou com andaimes [...]." (p. 122), como nos lembra Mazière, o que torna presente $o$ aspecto não-homogêneo do real com que esbarramos em nossa prática teórico-analítica, esse que não se permite engessar ou estabilizar pela intervenção de um instrumental infalível.

Com Robin e Guilhaumou, a seu turno, compreendemos mais situadamente os efeitos do encontro com Pêcheux no campo da História. Ponderamos, também, sobre a provisoriedade das filiaçóes teóricas e heranças deixadas sob a forma de atravessamentos prospectivos; sobre a problemática das apropriaçóes teóricas em $\mathrm{AD}$, de sua necessidade e desconfiança. Além disso, refletimos sobre o caráter crucial na criação de um ponto de vista sobre a materialidade discursiva, ao final dos anos 1970; das recusas; caducidades lexicais, e mesmo da transvaloração de conceitos como o de formação

\footnotetext{
${ }^{2}$ Nesse sentido, situa-se a problemática (da) recepção de $A$ inquietação do discurso, no Brasil, insinuada no texto resenhado.
} 
discursiva e condiçôes de produção. De Plon, finalmente, retemos a paixão e a admiração pela figura de um prático humilde, de origem proletária e cuja militância era sobremodo engajada, como foi Pêcheux, mesmo que, para isso, precisasse abrir caminhos polêmicos e pouco encorajados como o de estabelecer relaçóes entre marxismo e psicanálise.

Por fim, este consequente Encontros presenteia-nos com (outros) memoráveis e deslocadores (re)encontros, entre os quais é preciso destacar aquele que é possibilitado pela tradução urgente de uma das conferências apresentadas por Michel Pêcheux na Semana do Pensamento Marxista, promovida, em 1976, pela Faculdade de Ciências Políticas da Universidade Autônoma do México (Unam). Uma leitura sobre a qual não haverá spoiler, em que o filósofo apresenta questôes tão caras aos que se inclinam à compreensão dos processos sócio-histórico-ideológicos de produção dos sentidos. Uma vez mais Pêcheux, $\mathrm{e}(\mathrm{m})$ sua fala, impondo-se qual lâmina que corta no fastígio mesmo do voo para equivocar a potência, apresenta tatilidades na compreensão das relações sociais. Pêcheux, diríamos ressignificando João Cabral de Melo Neto - e compreenda-se como for possível -, insurge e não se encerra, como faca, "Uma faca só lâmina".

Trata-se, assim, de importante contribuição que nos é dada pelo Contradit em relaçáo à $\mathrm{AD}$ do lado da história e que nos permite tratar como "paradoxal" o discurso das colonialidades de saber/poder, que se antecipa no atual do nosso imaginário em relaçáo à prática teórica desde o Sul epistemológico, uma vez assumida a equivocidade no jogo resgate/ retorno, pela contradição implicada no par reproduçáo/transformação. A nossa visada sobre a história da $\mathrm{AD}$ des(co)loca-se e reinventa-se, sem isentar-se de uma retomada do que possa haver de estabilizado em relação a ela, especialmente no que se refere à problemática $(\mathrm{da})$ recepçáo do texto de Denise Maldidier, publicado no Brasil sob o título $A$ inquietação do discurso. 